\title{
地すべり形態に及ぼすボトルネック構造の影響 \\ The Influence of bottle neck structure on the behavior of landslide
}

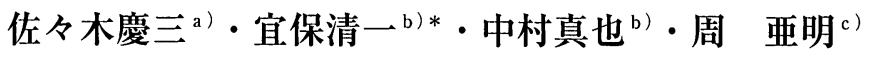 \\ Keizo SASAKI, Seiichi GIBO, Shinya NAKAMURA and Yaming ZHOU
}

\begin{abstract}
The number of sliding units in a landslide has greatly affected on the generation mechanism of the landslide. Bottle neck structure is one of the controlling factors of the landslide behavior, however, roles of the bottle neck structure are still not well known due to the limited number of published researches. The bottle neck structure is considered to provide controlling effects the development and direction of movement of the sliding unit. The mutual interaction between multiple bottle neck structures can develop to a single sliding unit which can ultimately cause a large-scale landslide.

Key words : huge landslide, geologic structure, sliding unit, bottle neck structure
\end{abstract}

\section{和文要旨}

地すべりが単独の移動体からなるか，二つ以上の移動体の集合からなるかは，地すべりの発生機構と媣くかかわる。地すべり形 態を規制する装因の一つにボトルネック構造があるが，公表事例が少なく，その役割は不明であった。ボトルネックは, 地すべり 移動体の分化と移動方向を規制する効果がある。また, 複数のボトルネックの相互関連によって, 単一の移動体からなる長大地す ベりを形成することがある。

キーワード：長大地すべり，地質構造，地すべり移動体，ボトルネック構造

\section{1.はじめに}

典型的な再活動型地すべりである崩積土地すべりの発 生機構の検討に当たり，すべり面の位置を基盤形状等と の関係を考虑し正確に求めることが重要である。これま での事例ではせん断応力が集中しやすい土質境界付近 （玉田, 1977）をすべり面としている場合が多い。また， すべり面形状，移動体形状等の情報は多用されている二 次元安定解析法では無視される (Chen \& Chameau, 1983 ; Leshchinsky \& Baker, 1986 ; 太田・林, 1998, 2001)。

一方，すべり面土の種類によっては停止時に残留状態 から様々なレベルの回復強度が出現することや, 残留強 度と垂直応力の関係は低い垂直応力領域下では湾曲化し ていることが明らかになっており(中村ら，1998，2000； 中村・宜保, 2000 ; 宜保ら, 2000 ; Gibo et al., 2002), 三次元安定解析法の導入による詳細な発生機構の検討も 行われている（太田・林，2001；中村ら，2004）。

崩積土を主体とする地すべり地では，地すべり形状が 曲がって滑動する現象が比較的多く見られるが，あまり 重要視されていないようである。しかし，著者らはこの 地すべり形状の屈曲は地すべり発生機構の検討だけでな く，地すべり対策を効果的に行う上でも極めて重要な意 味を持つと考えている。

地すべり方向が上部斜面と下部斜面で異なる現象は,

\footnotetext{
* 連絡薯者/corresponding author

）有限会社 ホソダエンジニアリング Hosoda Engneering inc.

b) 琉球大学㻃学部

Faculty of Agriculture. University of the Ryukyus

于903-0213 沖縄県中頭那酉原町千原1

Senbaru 1. Nishihara, Okinawa. 903-0213, Japan

c ) 株式会社 献城技術開発

Nanjyou Gizyutsukaihatsu Co.. Ltd
}

二つ以上の地すべり移動体が複合していて，見かけ上曲 がっているものと, 一つの地すべり移動体が地形や地質 条件に規制されているものの二つに区分される。地すべ り対策工法とその配置計画は両者で全く異なる。前者の 場合，基本的にはそれぞれの地すべり移動体で対策工法 を計画しなければならない（望月，1976）。後者の場合 は規模の大小を問わず，一つの地すべり移動体として主 働域，受働域を区分し，それぞれに対応した対策工法を 計画すれば良い。

地すべり移動体の分化，地すべり方向，すべり面深度 等の地すべり形態を規制する要因の一つにボトルネック 構造（藤原，1979）が知られている。ボトルネック構造 が地すべり形態にどのような影響を与えているかについ ては不明な点が多い。公表事例（地すべり学会新潟県支 部, 1993 ; 橋本ら, 2001）でもボトルネック構造そのも のについての記述はない。ボトルネックは，広辞苑（岩 波書店）では「(びんの狭い口の部分が，中身の自由な 出入りを妨げることから）隘路」と説明している。この ことから地すべりを規制する「ボトルネック構造」を「地 形や基盤構造の上方・下方に対する相対的な縮小部」と 定義する。ボトルネック部では単に地すべり幅が縮小す るだけでなく，地すべり移動体の分化や地すべり方向の 規制など様々な影響がある。また，ボトルネック構造が 複数の場合は相互の関連によって全く別の影響を地すべ りに与える場合もある。大所地すべりは複数のボトル

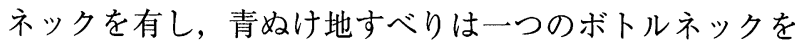

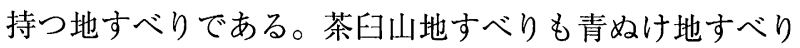
と同類のすべり形態を有しているようである。本研究は, これらの事例でボトルネック構造に注目し，地すべり形 
態におよぼす影響について検討したものである。

\section{2. 複数のボトルネック構造を有する大所地すべり}

\section{1 地すべりの特幑}

大所地すべりは姫川下流の左支川である大所川の支流, 木地屋川の中〜下流域に位置する（図－1）。大所川は 北アルプス北端の標高 $2400 \mathrm{~m} \sim 2800 \mathrm{~m}$ の朝日岳や雪倉岳 などに源を発し，北東流して姫川合流点の $2 \mathrm{~km}$ 手前て 木地屋川を合わせる。木地屋川は蒲原山（標高 $1629 \mathrm{~m} ）$ の西面を源頭とし，流域面積が $11.7 \mathrm{~km}^{2}$ である。木地屋 川の上流には風吹岳の火确流や以後の侵食作用などに よって形成された白池や杉の平などの緩斜面が広範囲に 発達している。地すべり頭部にあたる木地屋地区では， 旧期の地すべりと木地屋川によって開析された緩傾斜地 に，木地屋川によって供給された大量の土石流堆積物が 扇状地地形（高倉ら，1998）を形成すると共に，それ自 体が地すべり移動体となっている。また，これらの地形 に加えて，木地屋川が地すべり移動体を縦断して流下し ているので，広大な流域を有する木地屋川は地すべり地 への地下水供給源となっている。

大所川流域はフォッサマグナ西縁を通る系魚川ー静岡 構造線の西側にあたり，地質構造的には中，古生代の古 期岩類を主体とした飛騨外縁帯に対比される。古期岩類 は変成岩類, 非変成古生層, 中生代ジュラ紀の来馬層群 および中生代後期の珪長岩, 花崗岩類, 蛇紋岩などから 構成され，蛇紋岩は構造性のメランジェ体をなし，地す ベりの素因（茅原，1979；佐々木ら，2001）となってい る。これらを不整合に覆い風吹岳などに起源をもつ第四 紀更新世の溶岩㧍よび火山性砕屑岩類が広く分布する。 地すべり移動体はこれらの崖錐堆積物や火山性泥流堆積

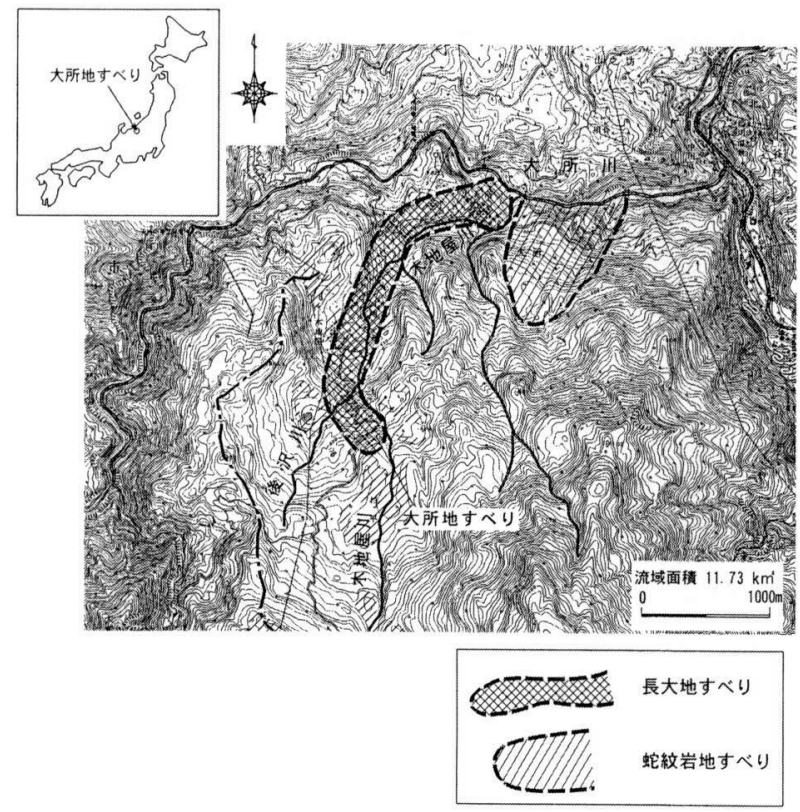

図一 1 大所地すべり位置図（2.5万分の 1 地形図「平岩」） Fig. 1 Location map of the O'dokoro landslide
物などからなる。

大所地すべりは，蛇紋岩メランジェ体に含まれる構造 岩塊を取り込む，地すべり長 $1000 \mathrm{~m}$ ，最大地すべり幅800 $\mathrm{m}$ ，最大すべり面樑度 $100 \mathrm{~m} の 大$ 大規模な蛇紋岩地すべり （新潟県土木部砂防課，1999；佐々木ら，2001）と火山 性泥流堆積物など未固結堆積物を移動体とする長大地す べり（日本地すべり学会新潟県支部，2002）からなる。 本文では後者の長大地すべりについて述べる。

地すべりを縦断して流下している木地屋川の侵食や堆 積作用が卓越して，地すべり地形が不明暸になっている ため，地すべりの規模は当初，長さ $1500 \mathrm{~m} て ゙$ 屈曲の少な い地すべりと考えられていた（高倉ら，1998）。その後の 調查で，冠頭部は杉の平北端の階段状滑落崖が発達して いる尾根にあり，末端部は法面工や橋台が破壊を受け， かつ基盤の蛇紋岩が露出している木地屋川の最下流部に あることが判明した。地すべり長は約 $2700 \mathrm{~m} ，$ 幅は $210 \mathrm{~m}$ 〜 350m, 地すべり層厚は $40 \mathrm{~m} \sim 60 \mathrm{~m}$ ，地すべり方向は頭 部で $\mathrm{N} 30^{\circ} \mathrm{W}$ ，末端部で $\mathrm{N} 80^{\circ} \mathrm{E}$, 全体で $110^{\circ}$ 曲がっている。

\section{2 地すべりの変状と移動方向}

地すべり冠頭部の杉の平北端尾根付近では，弧状を呈 する滑落崖が階段状に分布し，全体として高さ約 $50 \mathrm{~m}$, 傾斜約 $40^{\circ}$ の斜面が形成されている。地すべりの右翼側 方部は木地屋川のV字谷につながり，谷に建設されてい る堰堤群がせん断破壞している。左翼側方部は隣接する 地すべりの影響を受け，境界が不明暸であるが， 1 番目 のボトルネック付近では雁行ないし連続的な亀裂が見ら れる。地すべりはここから徐々に方向を変え，地すべり 左側部が屈曲の外側に，右側部が屈曲の内側になる。こ のため地すべりの変状は非対称的となり, 左側部では雁 行亀裂や溝状凹地など引張り応力が反映された微地形が 卓越する。1 番目のボトルネック付近から 3 番目のボト ルネックの区間には移動体を横断する二次滑落崖や亀裂 はない。

末端部では移動体内の家屋に広く圧縮性亀裂が見られ るほか，地すべり境界部の木地屋川では橋台や法面工に 顕著な亀裂，変形が現れている（図－2）。地表地質踏 查結果から，大所地すべりは，地すべりの長さ/幅が約 8 で，長さが2700mの長大な移動体と見なした。

GPS観測による対策工施工前の地すべりの移動量は, 頭部で $18 \mathrm{~cm} /$ 年，中間部で $11 \mathrm{~cm} /$ 年，末端部で 7〜 $8 \mathrm{~cm}$ /年と，末端に向かって漸減している。移動方向も北向 きから東向きに次第に変化しており, 観測結果と地表踏 查結果は一致した（図－2）(針生ら，2003）。

\section{3 地すべり形態とボトルネック構造}

大所地すべりの屈曲は基盤構造に起因したものと考元， ボーリング調查結果と弾性波探査結果を整理し基盤面等 深線図（図-3）と断面図（図-4,5）を示した。大 所地すべりの基盤構造には 3 つのボトルネックと最末端 に基盤の溝状凹部がある。最上部のボトルネックは地す ベり冠頭部から約 $500 \mathrm{~m}$ 下方にあり，地すべりの引張り 


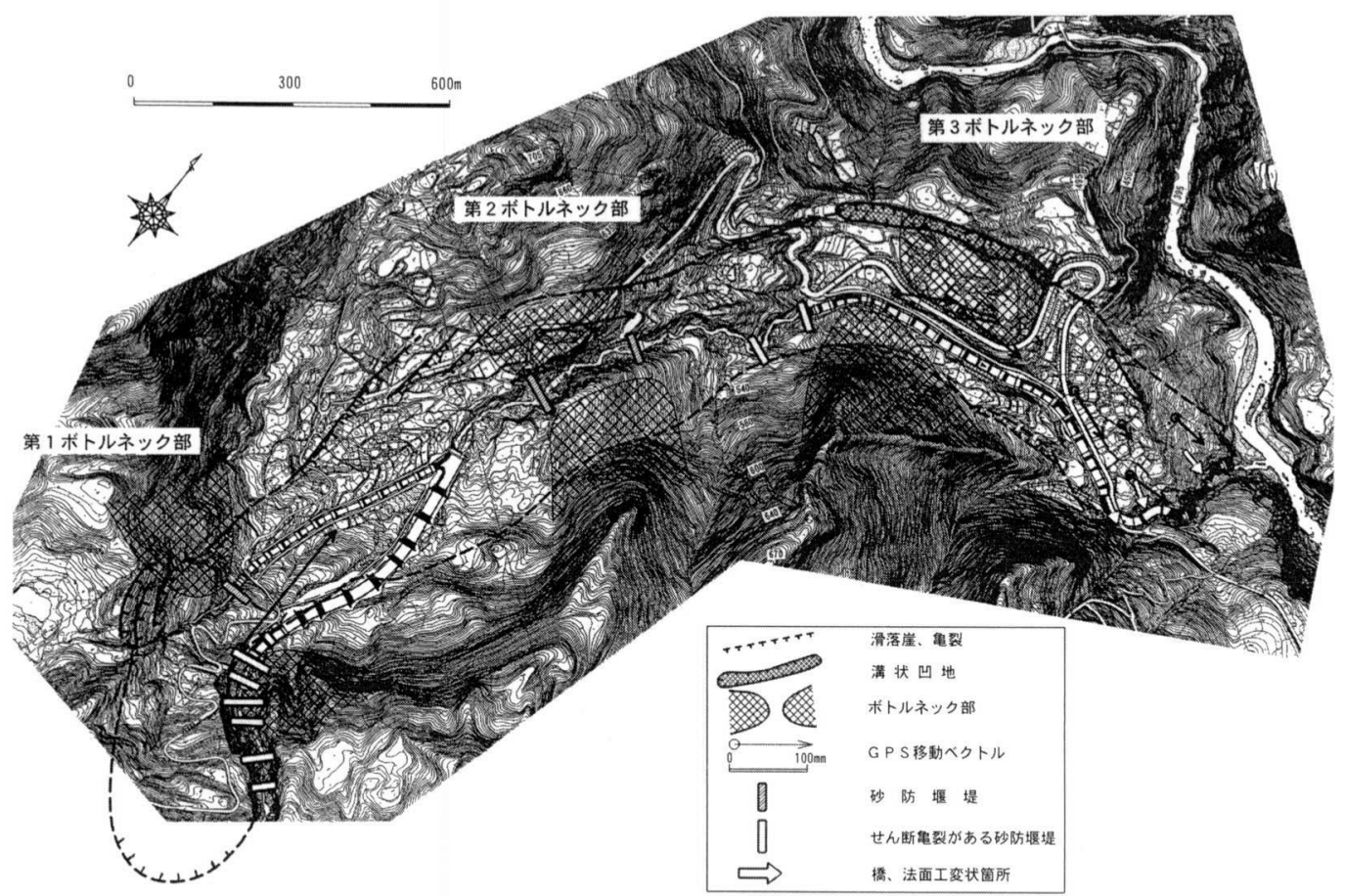

図一２大所地すべりのボトルネックと移動方向（日本地すべり学会新潟支部（2002）に加筆修正）

Fig. 2 Bottle neck structures and direction of movement of the O'dokoro landslide (modified from Niigata Branch of the Japan Landslide Society, 2002)

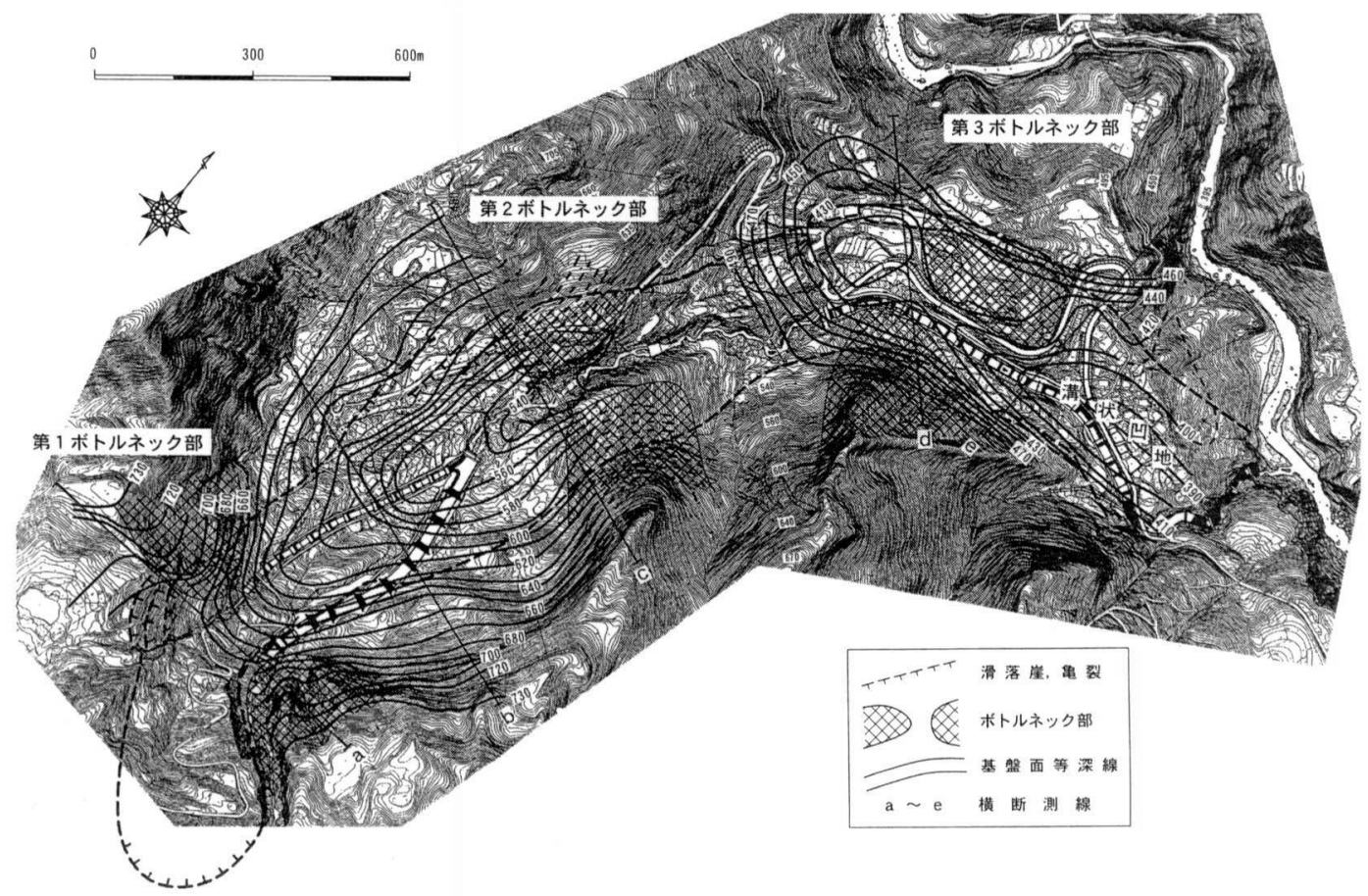

図一 3 大所地すべり基盤等深線

Fig. 3 Depth contours of bedrock of the O'dokoro landslide

部を形成する役割を果たしている。2 番目のボトルネッ クはそこから更に約 $800 \mathrm{~m}$ 下方にあり，1 番目との間に は緩傾斜地が広がっている。規制要因が無ければ地すべ り方向は北へ向かうはずであるが，2 番目のボトルネッ クが地すべり位置を固定しているために，緩傾斜地の位 置で強制的に曲げられている。このため, 地すべりは左
側に拡大し，地すべり幅が $350 \mathrm{~m}$ と最大になっている（図 - 3)。地すべりは地形的には更に膨らんでも良いが, ボトルネックがこれを抑制している。この地点では左側 部は隆起し，地すべり方向に大きく斜交する雁行亀裂が 発達している。また， 2 番目のボトルネックの下部の基 盤面は相対的に急傾斜となっているため, この地点では 


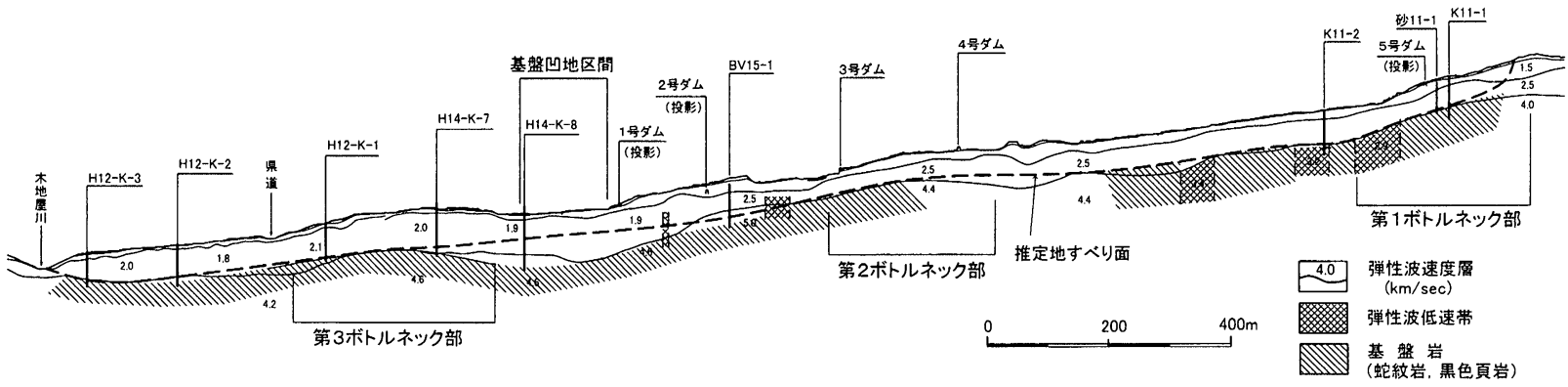

図ー4 大所地すべり地質断面図

Fig. 4 Geological section of the O'dokoro landslide

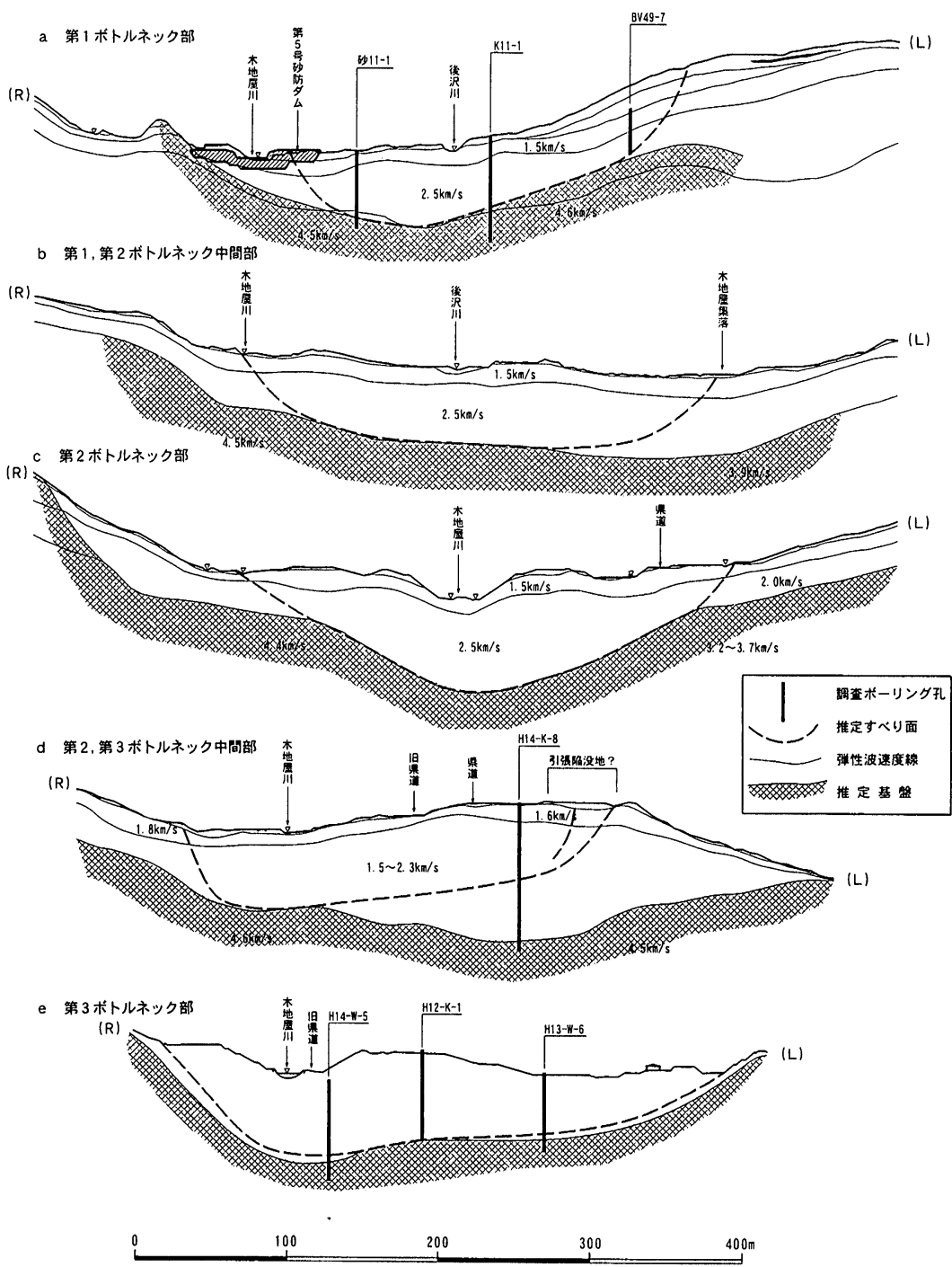

図一 5 大所地すべりボトルネック部の横断面

Fig. 5 Cross sections of bottle neck structure of the O'dokoro landslide

卓越する引張り力により地すべり移動体の分化がおきる はずであるが，実際には分化していない。これは，縦断 的には，基盤面は 2 番目のボトルネックの下部で急傾斜 で落ち込むが， $800 \mathrm{~m}$ 下流の 3 番目のボトルネックで再 び隆起し凸部を呈している。そして，すべり面は基盤凸 部をなぞるように，火山泥流堆積物中に形成されている (図一 4, $5 \mathrm{~d}$ )。このことが 2 番目のボトルネック付近
に引張り部が形成されなかった原因と考える。 3 番目の ボトルネックが， $800 \mathrm{~m}$ 上方の 2 番目のボトルネックの 影響を相殺する結果となっている。

3 番目のボトルネックの基盤形状は，平面的には左側 部の基盤の張り出しは長く延びて導流壁状を呈する。一 方，右側部は基盤面深度が低く，非対称な横断形状を呈 し(図- $3,5 \mathrm{e}$ ), 地すべり推力が右側へ向かう形状と 
なっている。すべり面が基盤面から離れ，火山性泥流堆 積物中に形成されている 2 番目と 3 番目のボトルネック の中間地点（図－ $5 \mathrm{~d}$ ）は地すべり方向が大きく変化す る地点でもある。ここでは，すべり面の形状と基盤形状 との間に何らの関係も見出せないが，地すべり方向の屈 曲が起きている。この原因は上下にあるボトルネックの 構造規制と考える。

3 番目のボトルネック下流側にも小規模ながら基盤の 急傾斜部が見られるが，右側の基盤凹部が，下流部の段 丘面下に埋没している砂碟を伴う基盤叫部に連続する (図-3)。

3 番目のボトルネック下流側の地すべり中央部付近の 平均すべり面傾斜は約 $4^{\circ}$ で, かつ, 未端の木地屋川渓 岸では「はね上がり」が見られる。3 次元的に見ると， 地すべりの主部は在側部の基盤面の最深部の位置に当た ると考えられるが，この位置での平均すべり面傾斜は約 $2^{\circ}$ である。これらは大所地すべりの主働域での平均すべ り面傾斜約 $6^{\circ}$ に比べて緩く, 全体として受働域を形成 していることから，3 番目のボトルネック付近でも地す ベり移動体の分化は起きなかったと考える。

\section{3. 一つのボトルネック構造を有する地すべり事例}

\section{1 青ぬけ地すべり}

青ぬけ地すべりは，大所地すべりと同じ飛騨外縁帯の 蛇紋岩メランジェ体に位置し, 珪質岩中の蛇紋岩部分が 激しい差別侵食を受けて，ボトルネック地形を形成して
いる（図一6，7，8）。なお図-7および 8 。おいて， ボトルネックの 1 - No. 2 孔の基盤岩深度を原図（地す ベり学会新潟県支部, 1993）の33.6mから $24.2 \mathrm{~m}$ に変更 した。これは，深度 0〜 24.2mまでが崩積土であること， パイプ軍計に深度 $23 \mathrm{~m} て ゙ 270 \mathrm{~mm} / \mathrm{day}$ 霆み累積がある 上，設置後16日で測定不能になったことから，ここをす ベり面とし, 深度 $24.2 \mathrm{~m}$ 以深の風化蛇紋岩を不動部と判 断したためである。このことは地すべり形態からも妥当 と考える。仮に原図のように基盤面傾斜がボトルネック の上下で一様ならば, 引張域は側方抵抗の大きいボトル ネック部を避けて下部斜面に形成され, 地すべり移動体 の分化はここで起きることになり笑際の地すべり現象と は合致しないことになる。

地すべり移動体はボトルネックで上下に分かれ，上部 斜面では方向の異なる地すべり移動体がボトルネック部 に向かう地すべり集合体をなす。この中にボトルネック を通過して下部斜面に向かう地すべり移動体が形成され ている。これの冠頭部（図-6, 中間平坦面）はボトル ネックから $200 \mathrm{~m}$ 上方にある。下部斜面では，上方から つながる 1 つの地すべり移動体が分布する（図-6）。 ボトルネックでは，時系列的には，下部斜面の地すべり 移動体の活動度合いに応じて, 引張り部と圧縮部の境界 が斜面上方へ移動したり下方へ移動したりする（日本地 すべり学会新潟県支部, 1993), 蛇腹運動をしていると言 われている。また，ボトルネックの下方域では地形が開 放された状態のため，地すべり移動体はボトルネックを

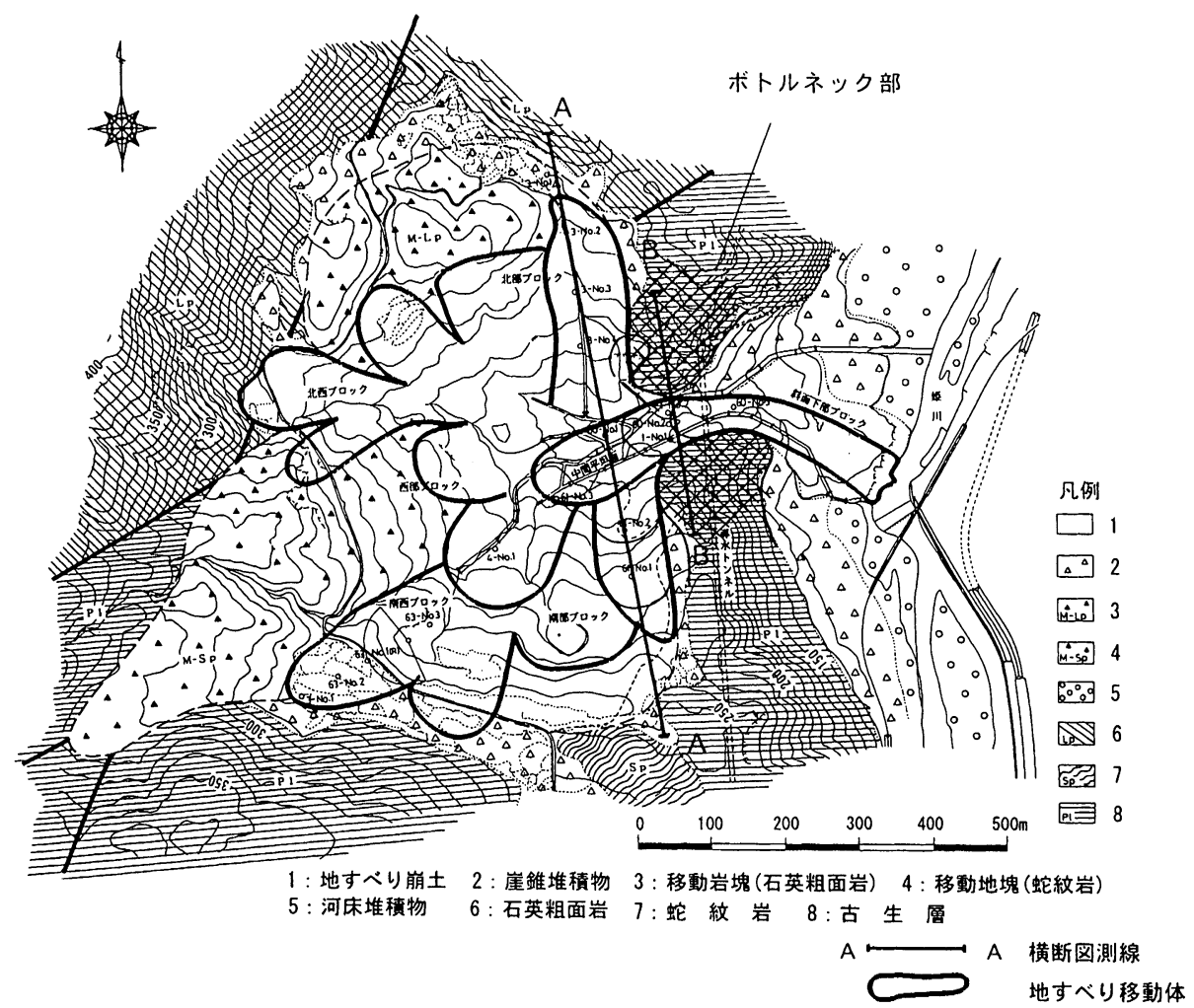

図－6＼cjkstart青ぬけ地すべりのボトルネック（日本地すべり学会新潟支部（1993）に加筆）

Fig. 6 Bottle neck structure of the Aonuke landslide (addition to Niigata Branch of the Japan Landslide Society, 1993) 


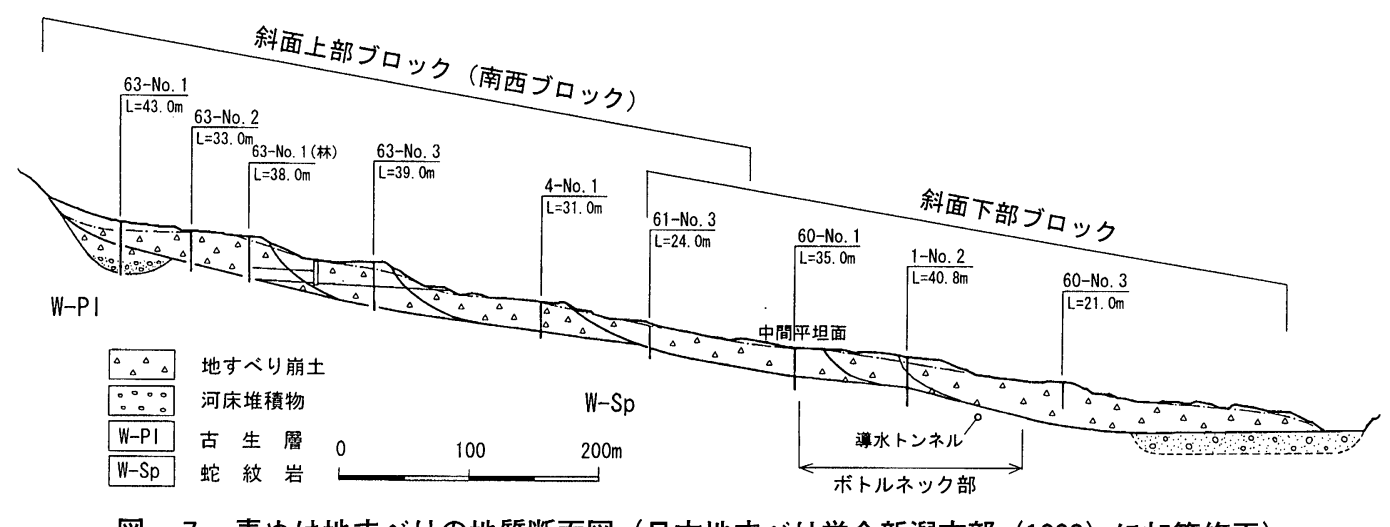

Fig. 7 Geological section of the Aonuke landslide (modified from Niigata Branch of the Japan Landslide Society, 1993)
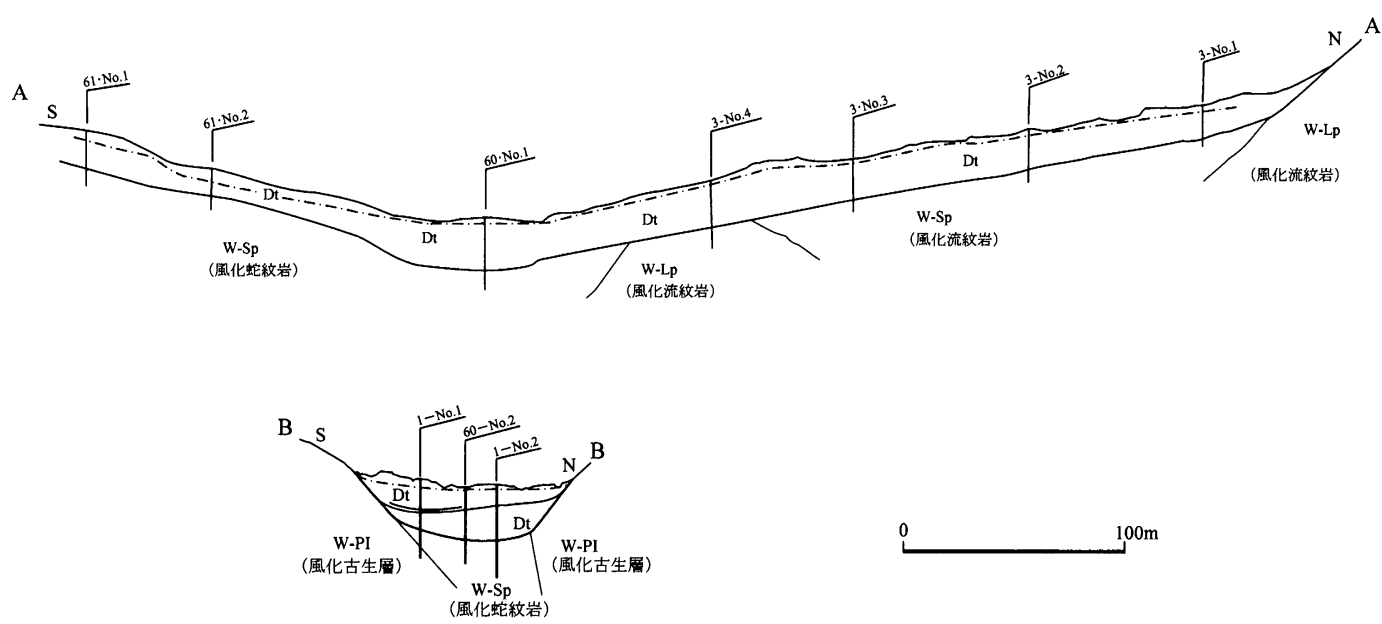

図一8＼cjkstart青ぬけ地すべりの横断面図（日本地すべり学会新潟支部（1993）に加筆修正）

Fig. 8 Cross sections of the Aonuke landslide (modified from Niigata Branch of the Japan Landslide Society, 1993)

基点に首振り現象を起こし，すべり方向が姫川の下流か ら上流側に変化した（現在は河道にほほ直交する方向に なっている)。

\section{2 茶臼山地すべり}

茶臼山地すべりは複雑で激しい活動をした大規模地す ベりとして知られている。長さが $2000 \mathrm{~m}$ 長大地すべり で，すべり方向が頭部で $445^{\circ} \mathrm{E}$ ，下部でおよそ $\mathrm{N} 75^{\circ} \mathrm{E}$, 全体で約 $60^{\circ}$ 曲がっている。地すべり幅は上方側で $180 \mathrm{~m}$ 〜 220m, 中央部の山新田地区一不動島付近では $140 \mathrm{~m} の$ 幅に狭まる特徴がある。望月（1977）は，上方側は地す べり発生地带（基盤岩型地すべり）, 下方側は二次的地 すべり地带（崩積土地すべり）として区分している（図 -9 )。

不動島付近で基盤岩が表層部に出る山体が分布する （望月・中村，1984）。不動島によって基盤面の形状が 2 段階の落ち込みになり (図-10), この結果地すべりが 2 列に分離し（渡，1999）, 地すべり移動形態が複雑に なっている。また，上方側地すべり発生地帯の左側部に 沿って流下する宇土沢川が, 山新田西方で南方に屈曲し, 滝沢川に合流していた（図－9）(望月，1977）ことと併 せ，ここに基盤岩の狭窄部，ボトルネックが形成されて
いると推定する。不動島上方側には斜め亀裂が形成され， 地すべり活動期には段差のある横断亀裂に替わられる (望月・中村, 1984)。斜め亀裂は, 上方側の広幅の地す ベりを斜めに切ることによって地すべり幅を狭め, 狭窄 部をすり抜けるための現象である。横断亀裂への変化は 上方側移動体と下方側移動体の相互作用に伴う移動体の 再配列であり，この地点で明瞭な移動体の分化が起きて いると考える。望月・中村（1984）も「地すべり発生地 帯と二次的地すべりの厳密な意味での境界は現在の不動 島西方の斜め亀裂の線であると言って良い。としてお り, 著者らと同じ考えである。また, 下方側移動体は下 流側に形成されている埋没谷にも規制され，すべり方向 や形態が変化している（望月・中村, 1984）。

\section{4. ボトルネック構造の役割}

ボトルネック構造については, 従来, 上下部斜面に対 する地形や基盤構造の相対的な縮小部と認識されている が, その特徵と地すべりに与える影響については明らか にされていなかった。地すべり移動体が分化しているか いないか, あるいは複数か単独か, すべり面がどの深度 に形成されているかは発生機構の検討や対策工法を計画 


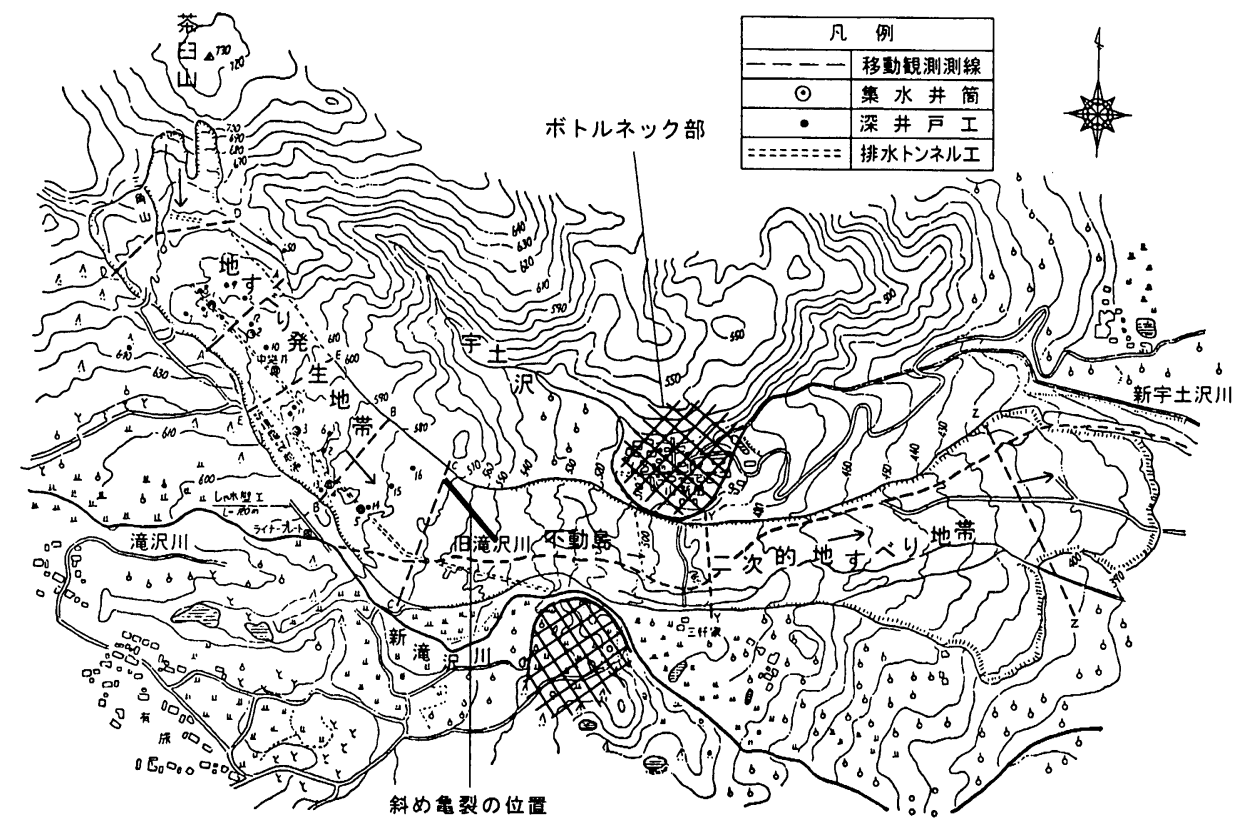

$0 \quad 100 \quad 200 \quad 300 m$

図ー9＼cjkstart茶臼山地すべりのボトルネック（望月(1977)に加筆）

Fig. 9 Bottle neck structure of the Tyausuyama landslide (addition to Mochizuki, 1977)

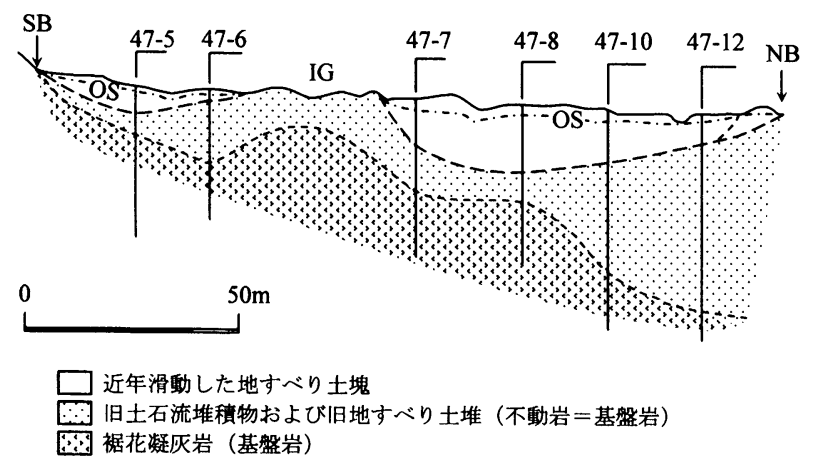

図一10 茶臼山地すべり不動島付近横断面図（望月・中村 (1984) に加筆)

Fig. 10 Cross section of the Tyausuyama landslide (addition to Mochizuki \& Nakamura, 1984)

する上で最も基本的で，重要な事項である。

地すべり移動体の分化や地すべり方向の変化はそれを 規制する条件があるものの，地表踏査やボーリング調査 から直ちにその条件を決定することは困難である。但し， 地すべり地に地形狭窄部が認められる場合には，地すべ り形態を規制する条件の一つとしてボトルネック構造を 仮定することは，効果的な地すべり対策の上でも大切で あると考える。

ボトルネックの構造は, 典型的なものから形状が不明 瞭なものまであり，それらの形状や位置の如何により地 すべり形態に与える影響は異なる。ボトルネック部では 平面的に両側から岩盤が張り出すだけでなく，縦断的に も張り出しがある。このため, 岩盤面の傾斜はボトルネッ ク上部で緩くなり，下部で急になる。地すべり移動体で 最大の圧縮部となるボトルネック部からその上方斜面に
かけての位置で，本体は形成されるはずのない引張部が 形成されるためにはボトルネック下部の岩盤面傾斜が急 になる条件が必要である。

青ぬけ地すべりで引張り部の位置が斜面の上下方向に 変化する蛇腹運動の事例や，茶臼山地すべりで斜め亀裂 と横断亀裂が形成された事例の主な原因は基盤の狭窄部 とその下部の基盤面が急傾斜であることが挙げられる。 ボトルネックの上部位置では，方向や幅の異なる地す ベりがボトルネック部を通過するために，地すべりが再 配列したり分化する現象が起きる。また，ボトルネック

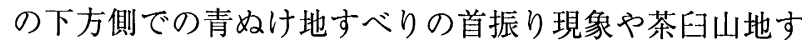
ベりの方向変化は，抵抗力が最小になる最も滑りやすい 方向へ変化したためであり，ボトルネックが下方側のす ベり移動体の頭部位置を固定化する役割を果たしている と推察される。

大所地すべりは，青ぬけ地すべりで見られるような， ボトルネックが単一の場合の地すべり形態に与える影響 が，複数になった場合にどのような相互関連のもとで地 すべり形態を規制するかの事例である。一般的に，ボト ルネックは平面的には地すべり方向を規制すると共に, 縦断的には移動体を分化させる役割を併せ持つ。このよ うな特徴にも関わらず，大所地すべりが $2700 \mathrm{~m} に 及 ふ ゙$ 単 一の移動体からなる長大地すべりを形成したのは, 複数 のボトルネックの相互関連に帰するものである。

ボトルネックは，平面的にも断面的にも地すべり形態 を規制するコントロールポイントとなり, 地すべり移動 体の方向変化や分化はボトルネック構造に左右される。 


\section{5. まとめ}

再活動型崩積土地すべりの発生機構については，すべ り面の強度特性もしくは安定解析手法などに関する最近 の知見に基づく検討が望まれることから，その基礎資料 となる地すべり形態を明らかにすることは重要である。

地すべりが単独の移動体からなるか, 二つ以上の移動 体の集合からなるかは，地すべりの発生機構と深く関わ る事柄である。地すべり形態を規制する要因の一つにボ トルネック構造があるが，その役割については公表事例 が少なく，不明であった。ボトルネック部は，平面的に は狭窄部，縦断的には凸部を形成するため，基盤形状は 上部で緩傾斜，下部で急傾斜となる。この結果，引っ張 り部を形成し，地すべり移動体を分化する働きがある。 また，平面的には地すべり位置を固定化する働きがあり， 地すべり方向が屈曲する場合のコントロールポイントと なる。

青ぬけ地すべり，茶臼山地すべりは一つのボトルネッ クによって二つの移動体に分化している。

一つの地すべり移動体が分化を起こさないためには, 移動体中に引張り力による二次滑落崖（龟裂）が形成さ れないことと，移動体が受働破壊を受けて抜け上がらな いことの二つの条件が必要である。

大所地すべりは長さ $2700 \mathrm{~m} の$ 長大地すべりであるが, 複数のボトルネックの相互関連によって，移動体中での 引張り力の発生が抑制されたことが原因の一つである。

受働破壊による抜け上がりは，すべり面深度とすべり 面土の強度などに規制されるが，この問題については今 後の課題としたい。

\section{謝 辞}

本研究をまとめるにあたり，2002年春，2003年春の 2 回にわたり木地屋川流域を含む現地勉強会を開催した。 適切な助言をいただいた新潟県系魚川土木事務所（現糸 魚川地域振興局）の五十嵐正信課長および関係諸氏に謝 意を表します。

\section{参考文献}

Chen, R. H. and Chameau, J. L.(1983) : Three-dimensional limit equilibrium analysis of slopes, Géotechnique, 32(1), 31-40.

藤原明敏（1979）：地すべりの解析と防止対策, p. 69, p. 345, 理 工図書.

Gibo, S., Egashira, K., Ohtsubo, M. and Nakamura, S.(2002) : Strength Recovery from residual state in reactivated Landslides, Geotechnique, 52 (9), pp. 683-686.

宜保清一, 中村真也，江頭和彦（2000）：地すべり土の残留強度と
物理的・鉱物学的性質との関係, 農業土木学会論文集, 210 , pp. $69-74$.

針生眞也, 三浦路子, 三石晋, 五十嵐正信, 小林健一（2003）：大 所地すべりの発生機構とその挙動, 日本地すべり学会誌, 40 (2), pp. $41-44$.

橋本純, 西尾克人, 阿部充訓, 木下恵 (2001)：岩屑なだれ堆積物 の末端部で発生したボトルネック型地すべり, 第40回日本地 すべり学会研究発表会講演集, 前橋, pp. 369-372.

茅原一也（1979）：姫川流域の崩災－特に蛇紋岩地帯の地すべり, フォッサマグナ北部地域における崩災の発生機構と予測に関 する研究成果報告, pp. 37-46.

Leschinsky, D. and Baker, R. (1986) : Three-dimensional slope stability: End effects, Soils and Foundations, 26 (4), 98-110.

望月巧一(1976)：最近の茶臼山地すべりの移動特性, 地すべり, 13 (2), pp. $1-12$.

望月巧一（1977）: 茶臼山地すべり発達経過からみた移動特性, 地 すべり, 14(1), pp. 28-38.

望月巧一, 中村三郎（1984）: 茶臼山地すべり下部の変動様相と埋 没谷，地すべり， $20(3)$, pp. 10-17.

中村真也, 宜保清一, 周要明, 江頭和彦 (1998): 地すべり土の残 留強度包絡線の湾曲化と強度定数決定方法, 地すべり，36(1), pp. $28-34$.

中村真也, 宜保清一, 江頭和彦, 吉永安俊 (2000)：地すべり土の 回復強度と鉱物組成の関係，地すべり，37(3), pp. 10-17.

中村真也, 宜保清一 (2000): 地すべり土の回復強度と垂直応力の 影響，地すべり，37(3)，pp. 18-24.

中村真也，宜保清一，林義隆（2004）：残留係数を導入した地すべ り三次元安定解析－沖縄，仲順地すべりについてー，農業土 木学会論文集, 229 , pp. 47-53.

日本地すべり学会新潟県支部（1993）：青册地すべりー構造線沿 いの活動中の地すべりー第21回地すべり現地検討会資料.

日本地すべり学会新潟県支部 (2002) : 大所地すべり一長大地すべ りの現況とその発生機構-第30回地すべり現地検討会資料.

新潟県土木部砂防課 (1999)：大所地すべり一大規模な破砕帯地す ベりの機構と対策についてー, 地すべり学会新潟支部第27回 現地検討会資料, 地すべり学会新潟支部.

太田英将, 林義隆（1998）：地すべり三次元安定解析の利用法（そ の 1 ), 第37回地すべり学会研究発表講演集, 長岡, pp. 441 -444 .

太田英将, 林義隆（2001）：周縁部摩擦効果を考慮した地すべり の 3 次元安定解析, 地すべり, 38(3), pp. 95-100.

佐々木慶三, 中村真也, 周亜明, 宜保清一(2001) : 姫川メランジェ の大規模地すべりの発生機構についての検討，地すべり， 37 (4), pp. 24-32.

高倉信幸，井上英将，木戸勇一，佐々木慶三（1998）：扇状地が地 すべりを起こしている事例－木地屋地すべりについてー，第 37回地すべり学会研究発表講演集, 長岡, pp. 167-170.

玉田文吾（1997）：口之津地区に扔ける表層地すべりの発生機構, 地すべり，14(3), pp. $1-6$.

高倉信幸，佐々木慶三，松本敏昭，竹内領（1998）：歪ネットを併 用した移動杭観測の事例, 第37回地すべり学会研究発表講演 集, 長岡, pp. 281-284.

渡正亮（1999）：地すべり対策の歴史と今後の問題，全国地すべり がけ崩れ対策協議会設立50周年記念講演会講演集, 東京, pp. $151-158$.

（原稿受付2004年 5 月11日，原稿受理2005年 2 月 14 日） 